\title{
A formação do professor de História no Brasil: percurso histórico e periodização
}

\section{The formation of the History teacher in Brazil: historic journey and periodization}

Thiago Rodrigues Nascimento*

\section{Resumo}

Nos últimos anos a formação de professores de História tem se tornado objeto de importantes pesquisas realizadas por historiadores e educadores. A vitalidade desse campo de pesquisa pode ser evidenciada no crescente número de trabalhos e artigos expostos e publicados em encontros, como os organizados pela Associação Brasileira de Ensino de História (Abeh), e em periódicos científicos. Entretanto, a maior parte dos estudos se debruça sobre as 'questões pedagógicas' e curriculares atuais, concedendo pouca atenção à história dessa formação. $\mathrm{O}$ artigo tem como objetivo apresentar e discutir uma periodização possível para análise da história da formação dos professores de História no Brasil. Para tanto, temos como referência teórica autores da história da educação e do ensino de História. Utilizamos, ainda, as diferentes legislações normatizadoras referentes à formação do professor de História no Brasil.

Palavras-chave: formação de professores; História; políticas públicas educacionais.

\section{Abstract}

In recent years the formation of history teachers have become the subject of significant researches by historians and educators. The vitality of this field of research can be traced by the growing number of papers and articles published and exhibited in meetings, such as those organized by the Brazilian Association of History Teaching, and in scientific journals. However, most studies focuses on both 'pedagogical' and current curriculum issues, giving little attention to the history of this formation. This article aims to present and discuss a possible timeline to analyze the formation of the history teacher in Brazil's history. Therefore, we have as a theoretical reference authors in the history of education and history teaching. We use also the different statutes regarding normalization of the history teacher's formation in Brazil.

Keywords: teacher's formation; History; educational public policies.

\footnotetext{
* Secretaria de Estado de Educação do Rio de Janeiro. thiagorodrigues.uerj@yahoo.com.br
} 
Na apresentação do livro Espaços de formação do professor de História Ernesta Zamboni e Selva Fonseca argumentam que os debates atuais sobre esse tema se inspiram no "movimento acadêmico internacional e nas políticas públicas educacionais". As historiadoras delimitam três pontos centrais para a discussão: 1) "as licenciaturas curtas/plenas em Estudos Sociais e História"; 2) as dicotomias bacharelado/licenciatura e teoria/prática na configuração dos cursos de História; e 3) a elaboração/implementação das Diretrizes Curriculares Nacionais para a Formação dos Professores da Educação Básica e dos Cursos de História a partir de meados da década de 1990. Tais aspectos estão intimamente interligados, ultrapassam o contexto atual e instigam diferentes problematizações.

O percurso que ora propomos se articula em torno das questões levantadas por Zamboni e Fonseca. Entretanto, ao nos aproximarmos da história da educação e das políticas públicas educacionais, tencionamos destacar que alguns aspectos das discussões atuais sobre a formação do professor e o lugar que esta ocupa na organização dos cursos de História não são tão recentes quanto se supõe ser. A dicotomia teoria/prática, por exemplo, é tão antiga quanto o estabelecimento dos primeiros cursos de História nas universidades brasileiras ao longo da década de 1930. A legislação educacional pensada e aplicada a partir dos anos 1990 está ligada a um movimento de repensar a formação do professor de História que tem início em finais da década de 1970, no bojo do processo de luta contra as licenciaturas em Estudos Sociais, e que prosseguiu nas décadas seguintes. As historiadoras Ilka Miglio de Mesquita e Ernesta Zamboni defendem que nesses anos constituiu-se "a luta pela formação de professores e por um outro ensino de História”. A produção sobre a história da formação de professores e sobre as práticas dos professores de História se associa a essa luta e ao processo de reconfiguração da Associação Nacional dos Professores Universitários de História (Anpuh) durante os anos 1970 (cf. Mesquita; Zamboni, 2008, p.130-162).

A partir das décadas de 1970 e 1980, com o ingresso de novos sócios, atuantes no ensino básico e na formação de docentes para esse segmento, a Associação teve de lançar seu olhar para a formação de professores de História e para o ensino dessa disciplina escolar, constantemente ameaçados pelos pressupostos estabelecidos pelas reformas educacionais implementadas pelo Conselho Federal de Educação (CFE). Tais tópicos passaram a ser uma 
constante nos Simpósios, livros e na publicação editada pela Anpuh - a Revista Brasileira de História (RBH). Selva Fonseca destaca, em artigo recente, que é preciso compreender a temática "formação de professores de História" como um campo de pesquisa que está iniciando sua história (Fonseca, 2012). As publicações, diálogos e encontros contribuem para a construção desse campo. Nesse movimento, tecemos uma história da qual somos narradores e personagens.

Apesar de existir uma rica produção sobre o ensino de História, "sua institucionalização enquanto disciplina universitária não tem sido examinada” (Ferreira, 2012). Trata-se de uma paisagem que começa a ser vislumbrada como uma possibilidade por educadores e historiadores. Ao enfrentarmos o difícil desafio que propõe o dossiê desta edição da Revista História Hoje, que é o de refletir sobre o lugar da formação do professor nos cursos de História, apresentamos uma periodização para a história da formação dos professores de História no Brasil. Para tanto, estabelecemos quatro marcos principais: 1) a constituição dos cursos universitários de História ao longo dos anos 1930; 2) a criação da Associação de Professores Universitários de História (Apuh) e o estabelecimento do Currículo Mínimo para os cursos de História, formulado pelo Conselho Federal de Educação (CFE), respectivamente, em 1961 e 1962; 3) a criação das licenciaturas em Estudos Sociais e o repensar da formação do professor de História nas décadas de 1970 e 1980; e, 4) as Diretrizes Curriculares e a formação do professor de História no início do século XXI.

\section{AS PRIMEIRAS EXPERIÊNCIAS DE FORMAÇÃO DE PROFESSORES DE HISTÓRIA NAS UNIVERSIDADES}

Marieta de Moraes Ferreira, em trabalho sobre a criação e institucionalização dos primeiros cursos de História no Brasil, salienta que a temática da criação das universidades no país tem sido objeto de inúmeras pesquisas ao longo dos últimos anos, porém "as abordagens adotadas têm privilegiado a análise das universidades no sentido amplo, apresentando um interesse menor por áreas ou campos de conhecimentos específicos" (Ferreira, 2006, p.139). Estudos recentes têm aberto esse campo de pesquisa, ainda que predomine a concentração dos trabalhos em torno das universidades que se instalaram no Rio de Janeiro e em São Paulo. Nesse contexto destacamos alguns trabalhos 
pioneiros. Ferreira tem se dedicado a analisar as missões francesas e o seu papel no processo de institucionalização dos cursos universitários de História no Rio de Janeiro a partir dos anos 1930. Sônia de Castro Lopes investiga o modelo de formação de professores na Universidade do Distrito Federal - UDF (19351939). Mônica Machado analisa a implantação da Geografia universitária no Rio de Janeiro na década de 1930. Diogo Roiz tem como objeto de estudo a institucionalização do ensino de História e Geografia na Universidade de São Paulo (USP) entre as décadas de 1930 e 1950. Com base nesses trabalhos podemos assinalar algumas características dos primeiros cursos de História e Geografia criados em universidades brasileiras (cf. Ferreira, 2011; 1999; Lopes, 2010-2011; Lopes, 2008; Machado, 2000; Roiz, 2007).

A primeira proposta surgiu com o projeto de Faculdade de Educação, Ciências e Letras da Universidade do Rio de Janeiro, que não chegou a ser organizada. Entretanto, é possível depreender com base no Art. 206 do Decreto $n^{\circ} 19.852 / 31$ que a formação em História e Geografia foi pensada no interior de um único curso, já que a habilitação se faria em História e Geografia. Nos anos seguintes, após publicação do Estatuto das Universidades Brasileiras (1931), duas experiências locais se efetivaram. Por meio de iniciativa do governo estadual foi criada, em 1934, a Universidade de São Paulo (USP), e durante a gestão de Pedro Ernesto à frente da prefeitura do Distrito Federal, foi fundada a Universidade do Distrito Federal (UDF). Segundo Lopes,

apesar da existência de uma base comum entre a USP e a UDF, ambas constituídas como expressões do ideário contido no Manifesto dos Pioneiros e voltadas tanto para a pesquisa científica como para a formação de professores, a UDF, por incorporar a concepção educacional de Anísio Teixeira, demonstrava maior preocupação com o preparo do magistério, enquanto a USP resultava de um projeto articulado aos interesses da oligarquia paulista, menos afeita à formação profissional e mais voltada para a pesquisa desinteressada. (Lopes, 2008, p.115)

A USP foi fundada poucos anos após a Revolução Constitucionalista de 1932. Para Ferreira, "enfraquecidos pelo movimento que em 1930 tinha trazido Vargas ao poder, os paulistas desejavam recuperar a sua posição política hegemônica no quadro nacional" (Ferreira, 1999, p.279). A Universidade tinha como uma de suas funções principais a formação intelectual das elites políticas paulistas. Para tanto, foi criada e incorporada em sua estrutura a Faculdade de 
Filosofia, Ciências e Letras, responsável pelo curso de História e Geografia. Essa faculdade tinha como objetivo a formação científico-cultural dos estudantes, e de acordo com Elza Nadai, "não se preocupava com a formação técnica profissional imediata” (Nadai, 1983). A formação pedagógica e profissional ficava a cargo do Instituto de Educação, também vinculado à Universidade.

Os primeiros cursos dessa instituição se constituíram no chamado modelo “ $3+1$ ”, isto é, três anos de formação específica (bacharelado) somados a um ano de licenciatura ou formação pedagógica. Após cursarem as disciplinas específicas do curso de História e Geografia, os discentes se dirigiam ao Instituto de Educação a fim de cursarem as disciplinas pedagógicas. Roiz analisa os currículos desse curso e, consequentemente, as suas diferentes reformulações ao longo de pouco mais de 20 anos. Para o autor, "no conjunto, o curso de Geografia e História limitava-se a caracterizar aos alunos as grandes linhas da História mundial e nacional, os aspectos geográficos do processo e a formação histórica e linguística do território brasileiro" (Roiz, 2007, p.77). Organizado em 3 anos, contava com disciplinas como Etnologia brasileira e noções de tupi-guarani, História da Civilização e uma disciplina intitulada Geografia, que atravessava os 3 anos. Com o desligamento do Instituto de Educação da Universidade, em 1938, a Faculdade de Filosofia, Ciências e Letras incorporou os estudos pedagógicos necessários à formação do professor. Assim, o Licenciado passava a ser aquele que concluísse o curso de Didática.

No Rio de Janeiro, a UDF se estruturou em diferentes órgãos: Instituto de Educação, Escola de Ciências, Escola de Economia e Direito, Escola de Filosofia e Letras, Instituto de Artes e Instituto de Artes para Experimentação Pedagógica. Esse projeto de Universidade refletiu um modelo integrado de formação de professores, em que formação profissional e conteúdos específicos não eram vistos de forma dissociada. Ferreira esclarece que:

Na visão de Anísio Teixeira, a universidade devia estar voltada para a produção do saber, e não apenas para a difusão e conservação dos conhecimentos, pois isso os livros já faziam. Tratava-se não de preparar simplesmente técnicos e professores, mas de formar um novo tipo de profissional, iniciado na pesquisa científica e crente na ação diretiva da educação. O projeto da UDF pretendia ainda estimular a formação de um novo tipo de intelectual, capaz de atuar com competência numa sociedade técnico-científica e democrática e integrar os objetivos da univer- 
sidade à vida pública e cultural do Rio de Janeiro e ao seu sistema de ensino básico. (Ferreira, 2006, p.142)

O projeto privilegiava a formação de professores, sem, no entanto, apartá-la das atividades de pesquisa como fio condutor do ensino, tal como advogava o Manifesto dos Pioneiros da Educação Nova (1932). ${ }^{1}$ Outra das propostas apresentadas nesse documento, e incorporada pela Universidade, foi a "unidade de formação de professores", já que oferecia um curso superior de formação de professores primários. A Escola de Economia e Direito da UDF tinha como "objetivo estudar a organização econômica, política e social do país", dedicando-se à formação de professores secundários de Geografia, História, Sociologia e Ciências Sociais. Para tanto estava dividida em cinco Seções de Estudos: Ciências Sociais, Ciências Econômicas, Ciências Geográficas e Históricas, Ciências Jurídicas, e Ciências Políticas e da Administração. Embora pertencessem à mesma Seção, História e Geografia eram cursos desenvolvidos de forma independente. Apesar de ter tido breve duração, tendo funcionado entre 1935 e 1939, a UDF apresenta dois projetos principais de formação de professores. Inicialmente o curso de História, dividido em 3 anos, compreendia disciplinas de conteúdo, específicas ao saber historiográfico; fundamentos, "matérias de cultura geral indispensáveis ao exercício do magistério da disciplina escolhida"; e as de integração profissional, que congregavam os estudos de educação propriamente ditos (Lopes, 2008, p.116-117). A formação pedagógica permeava todo o curso e não era um complemento à formação cultural ou específica.

Nos anos seguintes, o currículo sofreu algumas modificações indicadas por professores franceses, como Henri Hauser. Para o professor francês, "a formação pedagógica deveria ocorrer apenas no último ano", além de sugerir aumento da carga horária de disciplinas de conteúdo, tais como História Antiga e Moderna. Com essas reformulações a nova organização curricular passou a priorizar "um curso de conteúdo mais alargado e uma formação pedagógica feita a posteriori, menos preocupada em articular-se à formação cultural". ${ }^{2}$ A partir de 1937, as matérias pedagógicas passaram a ser oferecidas ao final do terceiro ano, com carga horária reduzida. A gradativa radicalização política, que chegou a seu ponto máximo com a instalação do Estado Novo em 
1937, levou ao processo de crise da UDF, culminando na sua extinção em janeiro de 1939 (Decreto-Lei no 1.063/39).

A UDF estava em descompasso com o projeto de ensino superior universitário que vinha sendo gestado pelo governo federal. Meses antes do golpe de Estado, havia sido criada a Universidade do Brasil pelas mãos do ministro da Educação Gustavo Capanema. Não era interesse manter, no Distrito Federal, duas universidades públicas. Em 1939, a UDF foi extinta e a maioria de suas escolas, cursos e quadros docentes e discentes foram transferidos para a Faculdade de Filosofia, Ciências e Letras da Universidade do Brasil, nomeada, a partir de abril daquele ano, como Faculdade Nacional de Filosofia (FNFi). Essa Faculdade foi organizada em quatro Seções, responsáveis por 11 cursos assim distribuídos: Seção de Filosofia (curso de Filosofia); Seção de Letras (cursos de Letras clássicas, neolatinas e anglo-germânicas); Seção de Ciências (cursos de Matemática, Química, Física, História Natural, Ciências Sociais e História e Geografia) e Seção de Pedagogia (curso de Pedagogia). A estas era acrescida a Seção Especial de Didática, responsável pela formação pedagógica dos professores secundários.

A principal alteração no que se refere à formação dos professores de História e Geografia foi a perda da autonomia. O curso de História passou a ser atrelado ao de Geografia. Após 3 anos de estudos, ao egresso desse curso conferia-se o título de bacharel em Geografia e História e, com mais 1 ano do curso de Didática, realizado na mesma Faculdade, obtinha-se o diploma de licenciado necessário ao exercício do magistério do curso secundário (Lopes, 2010-2011, p.130). As disciplinas da parte de História do currículo seguiam a perspectiva tradicional de divisão cronológica do conhecimento histórico (Quadro 1). Era concedida maior importância à formação específica, em detrimento da formação pedagógica, realizada de forma complementar à formação do bacharel no modelo " $3+1$ ". Na parte de formação específica, os futuros professores entravam em contato com o conteúdo a ser ensinado, e no último ano de formação eram expostas "as técnicas necessárias ao desempenho da tarefa de transmissão dos conteúdos adquiridos no primeiro momento" (Ayres, 2005, p.50). A Universidade do Brasil e seus cursos, a partir de 1939, tornaram-se o modelo a ser seguido em todo o território nacional. 
Quadro 1 - Currículo Mínimo do curso de História da Faculdade Nacional de Filosofia (Universidade do Brasil)

\begin{tabular}{|c|c|c|c|}
\hline $\mathbf{1}^{\mathbf{0}}$ ano & $\mathbf{2}^{\mathbf{0}}$ ano & $\mathbf{3}^{\mathbf{0}}$ ano & $\mathbf{4}^{\mathbf{0}}$ ano \\
\hline Geografia Física & $\begin{array}{c}\text { Geografia } \\
\text { Física }\end{array}$ & $\begin{array}{c}\text { Geografia } \\
\text { do Brasil }\end{array}$ & $\begin{array}{c}\text { Didática } \\
\text { geral }\end{array}$ \\
\hline $\begin{array}{c}\text { Geografia } \\
\text { Humana }\end{array}$ & $\begin{array}{c}\text { Geografia } \\
\text { Humana }\end{array}$ & $\begin{array}{c}\text { História } \\
\text { Contemporânea }\end{array}$ & $\begin{array}{c}\text { Didática } \\
\text { especial }\end{array}$ \\
\hline Antropologia & $\begin{array}{c}\text { História } \\
\text { Moderna }\end{array}$ & $\begin{array}{c}\text { História } \\
\text { do Brasil }\end{array}$ & $\begin{array}{c}\text { Psicologia } \\
\text { educacional }\end{array}$ \\
\hline $\begin{array}{c}\text { História da } \\
\text { da Idade Média }\end{array}$ & $\begin{array}{c}\text { História } \\
\text { do Brasil }\end{array}$ & $\begin{array}{c}\text { História } \\
\text { da América }\end{array}$ & $\begin{array}{c}\text { Administração } \\
\text { escolar }\end{array}$ \\
\hline & Etnografia & $\begin{array}{c}\text { Etnografia } \\
\text { do Brasil }\end{array}$ & $\begin{array}{c}\text { Fundamentos Biológicos } \\
\text { da Educação }\end{array}$ \\
\hline & & \multicolumn{2}{c|}{$\begin{array}{c}\text { Fundamentos } \\
\text { Sociológicos da Educação }\end{array}$} \\
\hline
\end{tabular}

Fonte: Decreto-Lei no 1.190, de 4 de abril de 1939.

Embora o currículo mínimo dos cursos não tenha sido modificado, o Decreto-Lei no 9.092, de 26 de março de 1946, alterou o sistema didático das Faculdades de Filosofia. Esse documento estabeleceu um novo regime para a obtenção dos diplomas de bacharel e licenciado. De acordo com o Art. 2º o diploma de licenciado ou de bacharel deveria ser conferido após 4 anos de estudos. Nos três primeiros, os discentes cursavam um currículo fixo de cadeiras, no caso da História e Geografia as estabelecidas conforme o Quadro 1, e no quarto ano do curso optavam por duas ou três cadeiras ou cursos dentre os ministrados pela Faculdade. O Art $4^{\circ} \$ 1^{\circ}$ esclarece que para obter o diploma de licenciado os alunos do quarto ano receberiam, ainda, a formação didática, teórica e prática, no ginásio de aplicação, e seriam obrigados a um curso de psicologia aplicada à educação. Não havia maior integração entre as cadeiras que compunham a parte de formação específica, muito menos destas com as disciplinas de cunho pedagógico.

Ferreira, analisando o caso da Faculdade Nacional de Filosofia, salienta que não havia uma "preocupação maior com o desenvolvimento de pesquisas e problemáticas ligadas a questões historiográficas e metodológicas”. Diferentes 
concepções de História e Geografia disputaram a primazia na constituição desses cursos. A distribuição das disciplinas de História e Geografia era feita de forma equilibrada, porém a comunidade de geógrafos não concordava com um curso único, defendendo a importância da Geografia para a educação moderna e salientando que o ensino de História e Geografia se processava de forma separada no ensino secundário. A separação definitiva dos cursos só ocorreria em meados da década de 1950.

\section{O Conselho Federal de Educação (CFE) e o Currículo Mínimo do Curso de História}

As décadas de 1950 e 1960 prenunciaram algumas das discussões que estariam em pauta após o golpe militar de 1964. O breve período entre 19451964, que separa dois governos ditatoriais, o Estado Novo (1937-1945) e o Regime Militar (1964-1985), foi fecundo para os debates educacionais. Em julho de 1959 veio à luz o "Manifesto dos Educadores mais uma vez convocados", reafirmando alguns pontos do "Manifesto dos Pioneiros da Educação Nova" (1932) e defendendo o dever do Estado com a educação pública, laica, obrigatória e gratuita. Redigido por Fernando de Azevedo, contou com signatários importantes no cenário educacional brasileiro, como Anísio Teixeira, Darcy Ribeiro, Florestan Fernandes e Sérgio Buarque de Holanda. Após 13 anos de intensos debates no Congresso Nacional Brasileiro, a Lei de Diretrizes e Bases da Educação Nacional (LDBEN) foi aprovada e sancionada em dezembro de 1961, pelo então presidente João Goulart (1961-1964). Alguns de seus artigos formam a base das reformas educacionais realizadas entre as décadas de 1960 e 1970. Nos artigos $8^{\circ}$ e $9^{\circ}$, que discorrem sobre a criação e funcionamento do CFE, ficava estabelecido, dentre outros aspectos, que " $\$ 5^{\circ}$ - as funções de Conselheiro são consideradas de relevante interesse nacional, e o seu exercício tem prioridade sobre o de quaisquer cargos públicos de que sejam titulares ou conselheiros" (Brasil, 1961, grifos nossos).

Iniciando as suas atividades em fevereiro de 1962, o Conselho tinha amplas atribuições, dentre as quais o poder de estabelecer currículos mínimos para o ensino superior e propor modificações no sistema nacional de ensino. ${ }^{3}$ No Art. 117 da Lei de Diretrizes e Bases de 1961 ficou estabelecido: "enquanto não houver número suficiente de professores licenciados em Faculdades de 
Filosofia, e sempre que se registre essa falta, a habilitação a exercício do magistério será feita por meio de exame de suficiência" (Brasil, 1961). Tal dispositivo, na Lei, lançou brechas sobre a obrigatoriedade, presente no Art. 59, de que a formação de professores para o ensino médio se processasse nas Faculdades de Filosofia, Ciências e Letras. Por meio desse mecanismo, o processo de seleção de docentes, ainda na década de 1960, continuava a se processar de forma improvisada. Priorizava-se o 'provimento' e não a formação. Os exames de suficiência lançaram as condições para que pessoas sem a formação necessária exercessem as atividades de ensino. Essa situação era em grande parte decorrente do lento processo de expansão das Faculdades de Filosofia pelas diferentes regiões do Brasil. Vera Candau assinala que,

de acordo com um Relatório do Inep, que utiliza dados referentes ao segundo semestre de 1949, o número total dessas faculdades no país é de 22, sendo 7 em universidades oficiais (Bahia, do Brasil, Minas Gerais, Paraná, Recife, Porto Alegre e São Paulo), 5 em universidades particulares, todas católicas (PUCs do Rio de Janeiro, Rio Grande do Sul, Campinas e São Paulo, esta última possuindo duas escolas), e 10 isoladas. (Candau, 1987, p.15)

As Faculdades de Filosofia se distribuíam, naquele momento, em apenas oito dos estados da Federação e concentravam-se, 19 delas, nas capitais dos estados. Estudos recentes têm demonstrado, para diversas regiões do país, as diferenças no processo de institucionalização da formação de professores nas Faculdades de Filosofia. Esse processo se iniciou nas cidades de São Paulo e Rio de Janeiro nos anos 1930, mas em muitos estados ocorreu algumas décadas depois. Letícia Carneiro Aguiar afirma em seu trabalho que:

Em Santa Catarina, até o início dos anos de 1960 a formação de professores acontecia nas Escolas Normais de $1^{\circ}$ ciclo (nível ginasial) e de $2^{\circ}$ ciclo (nível colegial) ...

Os primeiros cursos de formação de professores em nível superior de Santa Catarina surgiram no ano de 1960, na Faculdade Catarinense de Filosofia, que a partir desse ano passou a integrar a Universidade Federal (UFSC). Já na década de 1950, essa faculdade oferecia cursos de bacharelado em Filosofia, História e Geografia, Letras Neolatinas e Letras Anglo-Germânicas. Mas foi somente em fins de 1950 e início de 1960 que existiram condições objetivas para o oferecimento de cursos de licenciatura, com a criação dos cursos de Didática e de Peda- 
gogia. Em 1963 foi criada a Faculdade de Educação (estadual), também localizada na capital do estado, sendo que somente a partir de 1965, surgiram outros cursos de licenciatura em faculdades ou escolas superiores isoladas localizadas no interior do estado. (Aguiar, 2010, p.1-2)

Ao analisar o mesmo processo no estado da Paraíba, Francisco Chaves Bezerra aponta que a "Faculdade de Filosofia da Paraíba foi criada pelo governo do estado através do Decreto no ${ }^{146}$, de 5 de março de 1949, porém, começou a funcionar somente em 1952, composta pelos cursos de História e Geografia, Letras Neolatinas e Pedagogia, com sede na capital" (cf. Bezerra, 2007). A primeira Faculdade de Filosofia paraibana foi incorporada à Universidade da Paraíba em 1955, instituição federalizada em 1960. Esses exemplos são ilustrativos da expansão lenta e desigual das Faculdades de Filosofia pelos estados brasileiros. Segundo a análise de Candau, o processo de expansão dessas faculdades se acelerou a partir de 1960, chegando a triplicar, sobretudo, por intermédio da iniciativa privada. Isso não significa, necessariamente, que tenha nesses anos se formado um número maior de professores. Dados de 1960 informavam "que menos de $20 \%$ dos professores secundários são diplomados por faculdades de filosofia, emergindo eles das escolas normais e de outros cursos superiores" (Candau, 1987, p.15-16).

A formação de professores de História e Geografia, que ocorreu de forma conjunta até meados dos anos 1950, foi desmembrada a partir da Lei no 2.594, de 8 de setembro de 1955, assinada pelo presidente Café Filho (1955-1956) e pelo ministro Candido Motta Filho. Alunos de algumas universidades que ingressaram anteriormente à referida lei, como na Universidade do Brasil e na Universidade Federal de Juiz de Fora (UFJF), ainda foram habilitados, até início dos anos 1960, como professores de História e Geografia. A Associação Nacional dos Professores Universitários de História (Anpuh) - hoje Associação Nacional de História -, foi fundada em 1961, nesse momento de afirmação dos cursos de História, independentes dos cursos de Geografia. Inicialmente denominada Associação de Professores Universitários de História (APUH), era composta por professores vinculados a instituições como a Universidade do Brasil e a USP. Nas palavras de Maria do Carmo Martins, "como uma associação científica fundada por professores-pesquisadores, a entidade manteve seu caráter acadêmico, com atividades de divulgação de trabalhos de pesquisa histórica, discutindo, 
quando muito necessário, o ensino superior e a formação de professores" (Martins, 2000, p.111, grifos nossos). Entretanto, é preciso destacar que no $1^{\circ}$ Simpósio de Professores de História do Ensino Superior, realizado na Faculdade de Filosofia, Ciências e Letras de Marília (São Paulo), a formação dos professores de História e a necessidade de mudança nos currículos foram amplamente abordadas. Na ocasião, ocorreram Conferências, como a proferida pelo professor Pedro Calmon, então reitor da Universidade do Brasil, sobre a História do Brasil, e sete sessões que versaram sobre diferentes temas.

De acordo com os Anais do evento, publicados em 1962, cada um dos tópicos em pauta ficou sob responsabilidade de um relator. Os temas e seus coordenadores foram assim definidos: I - História Antiga e História Medieval: dois espíritos e duas especializações. Problemas que suscita a sua definição numa só Cadeira, Eurípedes Simões de Paula; II - História Moderna e História Contemporânea: problemas que suscita o seu ensino numa só Cadeira, Eduardo D’Oliveira França; III - O estudo da História da América e da História do Brasil no curso universitário: ensino tradicional e renovação, Alice Piffer Cannabrava; IV - Matérias complementares e auxiliares: o alargamento do horizonte no estudo da História, Eremildo Vianna; V - O lugar das disciplinas pedagógicas no curso de História, Maria Yedda Leite Linhares; VI - A especialização. As condições por ela pressupostas e as possibilidades inerentes ao curso de História do Brasil, Carl Valler Frans Laga; VII - Reestruturação do currículo, Olga Pantaleão.

$\mathrm{Na}$ Introdução dos Anais do Simpósio, os organizadores argumentam "que foram postos em questão, senão todos, ao menos uma grande parte dos problemas que enfrenta o ensino de História no Brasil”. ${ }^{4} \mathrm{O}$ foco, como não podia deixar de ser, centrava-se no ensino de História no nível superior. As questões eram muitas. A principal era a necessidade de reestruturação do currículo mínimo do curso de História em todas as suas áreas. A separação dos cursos de História e Geografia em 1955 não foi acompanhada pela construção de um novo currículo mínimo oficial para os cursos independentes. As disciplinas principais continuaram as mesmas estabelecidas pelo Decreto-Lei $\mathrm{n}^{\circ}$ 1.190, de 4 de abril de 1939. Embora o curso ministrado pela Universidade do Brasil tenha permanecido como a grande referência para os outros, cada Faculdade de Filosofia e Departamento responsável por ministrar os cursos de História propuseram acréscimos, sem, no entanto, haver uma uniformidade nacional. A importância da Faculdade Nacional de Filosofia fica patente na 
escolha de Maria Yedda Linhares, professora catedrática de História Moderna e Contemporânea, e Eremildo Vianna, então diretor da referida Faculdade, para relatar importantes temas do Simpósio.

Analisar os múltiplos aspectos expostos pelos relatores em suas sessões fugiria aos objetivos principais deste trabalho, porém, por sua maior ênfase nas questões referentes à formação do docente de História, cumpre destacar alguns pontos da palestra de Linhares. ${ }^{5}$ No início da apresentação de seu relatório, a historiadora observa que a formação de professores para a educação média se incluía entre os principais problemas com que se defrontavam os educadores brasileiros na conjuntura do ensino superior. Portanto, tal problema não poderia ser tratado isoladamente, isto é, sem ser situado no plano geral da Universidade e, mais ainda, da necessidade de reforma urgente no ensino universitário. Uma reforma na Universidade passava, necessariamente, por uma reformulação dos objetivos das Faculdades de Filosofia. Concebida durante os anos 1930, no bojo dos movimentos que culminaram com o fim da República Velha (1889-1930), como órgão integrador responsável por ministrar o ensino básico na Universidade, formar os professores para atuar no então ensino secundário e preparar o "pesquisador desinteressado da cultura", teve, ao longo das décadas seguintes, seu projeto inicial desvirtuado. A função de núcleo aglutinador das atividades desenvolvidas na Universidade se perdeu, restando as tarefas de formação do professor e do pesquisador.

É, sobretudo, visando essas tarefas que as Faculdades de Filosofia se expandiram, de forma lenta, pelo país. Salienta Maria Yedda Linhares que nos anos 1960 o Brasil havia mudado significativamente, mas não a sua estrutura de ensino superior. O ensino básico havia crescido significativamente desde os anos 1930; profissionais com nível universitário, para além dos bacharéis em Direito, Medicina e Engenharia, estavam sendo requisitados, e a pesquisa passava a ser uma reivindicação de setores da Universidade que até então não tinham essa preocupação imediata. Quanto aos currículos dos cursos ministrados nas Faculdades de Filosofia, a autora argumenta que:

A duplicidade de funções: formar professores e pesquisadores num mesmo currículo, tem contribuído para que nenhuma das duas seja adequada e eficientemente exercida, mesmo nas mais ricas e mais bem dotadas em pessoal docente. A experiência tem demonstrado, naqueles centros em que ambas estão presentes, a interferência perturbadora de dois objetivos simultâneos no ciclo dos cursos de 
formação. Daí a necessidade hoje sentida de serem definidas, através dos currículos flexíveis, as duas funções que se tornaram básicas nas Faculdades de Filosofia do país. (Linhares, 1962, p.167)

O currículo era uniforme, ou seja, era o mesmo para o bacharelado e para a licenciatura. A única diferença residia no acréscimo de disciplinas pedagógicas no que concerne à habilitação em licenciatura. Traçando um quadro da formação nos cursos de História, Linhares aponta que estes estavam formando 'autodidatas'. Aquele que objetivava o magistério formava-se sozinho, e os que aspiravam à experiência de pesquisa eram levados às universidades estrangeiras (p.169). Quanto à distribuição das disciplinas, no que tange à História, o quadro era desolador (p.170):

Durante três anos, recebe o aluno doses mais ou menos maciças de conteúdo, isto é, História Geral, História do Brasil e da América; no sistema de cátedras vigente, tais Cadeiras se ignoram quando não se hostilizam ... O aluno, mal preparado e mais das vezes confuso, ingressa, então, na quarta série para lhe serem ministradas as disciplinas pedagógicas, também, distribuídas pelo sistema de cátedras. Tais disciplinas, sem articulação com as matérias de conteúdo resultam inúteis no caráter formativo e incorrem no erro, observado no caso específico da Didática, de transmitir conceitos e fórmulas desvinculados da realidade social. (p.170)

A autora apresenta duas ausências de articulação. A primeira entre as disciplinas de conteúdo, cujo ensino dependia dos ânimos e vontades do catedrático responsável, e a segunda entre estas e as disciplinas ditas profissionais ou de formação pedagógica. Para a historiadora, a Didática enfocava técnicas estranhas ao contexto educacional brasileiro, importadas de outros países. Em grande parte esse aspecto se devia ao não contato entre as Faculdades de Filosofia e as escolas. O discente dos cursos de História recebia, na perspectiva de Maria Yedda Linhares, uma formação parcelada e que pouco o auxiliava. $\mathrm{O}$ 'que ensinar' estava distanciado do 'como ensinar'. Ao fim de seu relatório a historiadora apresentou um documento, intitulado "Propostas para aplicação imediata", elaborado por comissão composta por Amélia Americano Franco Domingues de Castro, Guy de Hollanda e Altiva Pillati Pallana. Sugeriu-se a revisão dos currículos pelos Departamentos de História, estabelecendo uma maior integração entre a Didática e as disciplinas básicas; a criação de Colégios 
de Aplicação onde não existissem, bem como a sua integração no âmbito das Faculdades de Filosofia e das escolas, com os formados em História ministrando Didática especial. A comissão sugeriu, ainda, requisitos mínimos para a formação do professor de História, os quais se limitavam a três disciplinas: Teoria Geral da Educação, através de teorias pedagógicas e suas aplicações; Didática especial de História, e Psicologia do adolescente e aprendizagem. No documento não aparecem referências a reformulações nas disciplinas de conteúdo e sua relação com a formação do professor. Recomenda-se a análise de programas e compêndios de História em Didática especial e a criação de cursos de aperfeiçoamento (de conteúdo e didática) destinados aos professores do ensino secundário. A professora Amélia de Castro, durante seus comentários ao relatório, defende a distribuição das disciplinas pedagógicas ao longo do currículo. Essa era uma reivindicação de um grupo de educadores brasileiros e não obteve ressonância entre os participantes do Simpósio.

No ano seguinte (1962) aos debates realizados pelos professores universitários de História, na cidade de Marília, em pleno auge das discussões sobre a necessidade de reforma curricular, o CFE fixou o novo currículo mínimo para os cursos de História. No Parecer 377/62, aprovado em 19 de dezembro, o relator, conselheiro Newton Sucupira, argumenta que esse currículo se destinava à "preparação do professor da escola média”, e em função desse objetivo é que fora organizado. No documento o relator distinguia historiador e professor de História. Para ele, o professor de História não precisava ser necessariamente um historiador, mas devia possuir uma sólida formação em sua matéria. Na elaboração da matriz que deveria guiar a estruturação dos cursos, eram priorizadas as categorias utilizadas pelo historiador no seu ofício. O currículo deveria estar orientado para "o estudo da história em profundidade", mas o conhecimento do fato histórico não seria útil se o discente não lhe desse uma interpretação. Assim, as disciplinas se propunham "ao conhecimento aprofundado da realidade histórica e dos processos e métodos com os quais se faz a história como ciência”.

Com base nesses pressupostos, três ordens de disciplinas compunham o currículo de História: 1) as matérias históricas propriamente ditas, distribuídas na divisão cronológica tradicional; 2) disciplinas culturais de complementação, que contribuem para a compreensão do conhecimento histórico; e, 3) disciplinas onde se estuda o método histórico, "em razão dos objetivos específicos do curso". Na organização curricular estabeleceu-se uma parte fixa, composta 
pelas disciplinas históricas propriamente ditas (História do Brasil, por exemplo) e por uma disciplina de método (Introdução ao estudo da História), e a parte variável, escolhida em ampla lista proposta pelo Conselho ou pelas Faculdades que se propusessem a ministrar os cursos de História. Essa parte se constituiria pela opção por duas disciplinas. A responsabilidade pela formação pedagógica do professor continuava a cargo dos Departamentos ou Faculdades de Educação. Aos que desejassem o diploma de licenciado eram exigidas as matérias pedagógicas, tal como disposto no Quadro 2.

Quadro 2 - Currículo Mínimo do Curso de História (1962)

\begin{tabular}{|c|c|c|}
\hline Parte Fixa & Parte Variável & Licenciatura \\
\hline $\begin{array}{c}\text { Disciplinas } \\
\text { Obrigatórias }\end{array}$ & Disciplinas Complementares & Matérias Pedagógicas \\
\hline $\begin{array}{c}\text { Introdução ao } \\
\text { estudo da História }\end{array}$ & Sociologia & $\begin{array}{c}\text { Psicologia da Educação } \\
\text { (Adolescência e } \\
\text { Aprendizagem) }\end{array}$ \\
\hline História Antiga & Antropologia Cultural & $\begin{array}{c}\text { Elementos de } \\
\text { Administração Escolar }\end{array}$ \\
\hline História Medieval & $\begin{array}{c}\text { História das Ideias Políticas } \\
\text { e Sociais }\end{array}$ & Didática \\
\hline História Moderna & $\begin{array}{c}\text { História Econômica } \\
\text { (Geral e do Brasil) }\end{array}$ & $\begin{array}{c}\text { Prática de Ensino } \\
\text { (Estágio Supervisionado) }\end{array}$ \\
\hline História & História da Arte & \\
\hline Contemporânea & Literatura Brasileira & \\
\hline História da América & História da Filosofia & \\
\hline História do Brasil & Geografia (Geo-história) & \\
\hline & Filosofia da Cultura & \\
\hline & Civilização Ibérica & \\
\hline & Paleografia & \\
\hline
\end{tabular}

Fonte: Parecer 292/62 (Formação pedagógica nas licenciaturas), aprovado em 14 de novembro de 1962.

Parecer 377/62 (História. Habilitação única: licenciatura), aprovado em 19 de dezembro de 1962. 
O currículo elaborado pelo CFE passou ao largo das discussões processadas durante o I Encontro de Professores Universitários de História, realizado em Marília. A formação do professor era entendida pelo binômio "conhecimento dos diferentes conteúdos que compunham a matéria a ser ensinada", neste caso a História, e "estudos profissionais que habilitavam ao exercício do magistério". Essas duas instâncias da formação do professor não dialogavam. Na prática, o modelo continuava a ser o " $3+1$ ”, já que a formação pedagógica continuava a ser realizada como uma complementação à formação específica ou bacharelado. Durante as décadas de 1960 e 1970, com a maior atuação do CFE, uma nova lógica de formação de professores foi gestada. Novos elementos foram inseridos, e outra modalidade de licenciatura foi criada.

\section{Dos ‘ANOS DE CHUMBO’ AO REPENSAR DA FORMAÇÃO DOS PROFESSORES DE HistóRIA}

Em 1964 um golpe civil-militar derrubou o presidente João Goulart e iniciou-se o que seria a mais longa ditadura brasileira. Após o golpe de 1964, se processaram importantes modificações na política educacional, que podem ser observadas nas reformas do Ensino Superior (Lei 5.540/68) e de Ensino de $1^{\circ}$ e $2^{\circ}$ graus (Lei 5.692/71). Segundo Elza Nadai, "modificações legais impuseram ainda profundas transformações no projeto de formação de professores que vinha sendo realizado, tornando-o de 'curta duração', pobre em conteúdo científico, aligeirado e polivalente" (Nadai, 1992-1993). Negou-se à História o seu caráter autônomo com a inclusão dos Estudos Sociais, componente curricular que integrava a História e a Geografia, no currículo do ensino de $1^{\circ} \mathrm{grau}$, e com a diminuição da carga horária da disciplina no $2^{\circ}$ grau.

Amparado pela Lei de Diretrizes e Bases da Educação Nacional, aprovada pelo Congresso brasileiro em 1961, o conselheiro Newton Sucupira, do CFE, na Indicação $\mathrm{s} / \mathrm{n}^{\circ}$ "Sobre o exame de suficiência e formação do professor polivalente para o ciclo ginasial”, de 9 de outubro de 1964, propôs a criação de licenciaturas polivalentes em Ciências, Estudos Sociais e Letras. Aprovadas pelo Conselho "em caráter experimental", teriam duração de 3 anos e se destinariam à formação do professor do ensino ginasial (cf. Nascimento, 2012). As licenciaturas curtas ou de $1^{\circ}$ Ciclo seriam: a de Letras, compreendendo o ensino de Português e de uma língua viva; a de Estudos Sociais, habilitando ao 
magistério de História, Geografia e Organização Política e Social do Brasil; e a de Ciências, para o ensino de Ciências Físico-Biológicas, Iniciação às Ciências e Matemática.

O Parecer 106/66 do CFE, relatado por Newton Sucupira, argumentava que esses cursos deveriam "fornecer professores polivalentes para as matérias fundamentais ao primeiro ciclo onde se verificava o maior índice de expansão da escola média”. No mesmo Parecer o relator sugeria a interiorização dessas licenciaturas, já que as maiores carências de professores licenciados estavam no interior (Sucupira, 1966). Seguindo essa argumentação, o conselheiro afirma que "sendo de mais modestas exigências, tais licenciaturas se tornam mais acessíveis no interior”. O Currículo Mínimo do Curso de Estudos Sociais se constituiria mediante o seguinte conjunto de matérias: História (Antiga, Moderna, Contemporânea e do Brasil, Organização Social e Política do Brasil); Geografia (elementos de Geografia Física, Humana e do Brasil); Fundamentos de Ciências Sociais; e formação pedagógica. O diploma do curso habilitava para o ensino de História e Geografia, Organização Social e Política do Brasil e Estudos Sociais (disciplina que não constava da Indicação s/no de 1964). A partir das reformas de ensino, realizadas entre 1968 e 1971, as licenciaturas curtas foram generalizadas e, no caso do curso de Estudos Sociais, houve necessidade de reformulação do currículo mínimo.

O Parecer 554/72, de 8 de junho de 1972, e a Resolução no 8/72, de 9 de agosto, de autoria do conselheiro Paulo Nathanael de Souza, do CFE, estabeleceram o Currículo Mínimo para a habilitação em Educação Moral e Cívica. ${ }^{6}$ De acordo com o Parecer existiam duas possibilidades ao se fixar o mínimo dos cursos de formação de professores para o ensino de Educação Moral e Cívica no $1^{\circ}$ e $2^{\circ}$ graus. A primeira o considerava como uma licenciatura à parte, à semelhança das licenciaturas em História, Geografia ou Ciências Sociais, e a segunda o considerava como uma modalidade do curso de Estudos Sociais, com seu currículo devidamente modificado. Optou-se por este segundo caminho, levando-se em consideração a ideia de economicidade, ou a não duplicação de meios para fins idênticos, propagada pela legislação educacional. O relator argumenta que Educação Moral e Cívica e os cursos de Estudos Sociais, bem como as licenciaturas em História, Filosofia ou Geografia, compartilhavam de uma "área de estudos comum", compondo uma mesma família, 
pois "visam conjuntamente à formação de professores que irão manejar o mesmo instrumental didático, apenas com prismas e dosagens diversificadas".

Poderíamos indagar o porquê da opção por fixar a Educação Moral e Cívica como uma habilitação da licenciatura em Estudos Sociais e não de História ou Geografia, por exemplo. Nathanael argumenta que o ensino dessa disciplina envolvia aspectos filosóficos, sociais, históricos e geográficos, sendo, portanto, em sua visão, a licenciatura em Estudos Sociais a mais adequada para a habilitação em Educação Moral e Cívica. Enquanto as graduações em História e Geografia priorizavam o ensino de um saber específico, a formação em Estudos Sociais proporcionava uma visão mais ampla ao propor a polivalência, isto é, a capacidade do professor para atuar em diferentes níveis de conhecimento e de ensino.

O conselheiro apresenta uma concepção de licenciatura curta e defende esse tipo de formação. Retoma a Indicação s/nº de 1964, elaborada pelo conselheiro Sucupira, salientando a experiência da licenciatura curta como uma das "mais ricas e frutuosas que se ensaiaram nos sistemas de ensino". O êxito desse projeto teria sido um dos principais fatores que levaram à sua consagração definitiva nas Leis de Reforma do Ensino Superior (1968) e do Ensino de $1^{\circ}$ e $2^{\circ}$ graus (1971). Assim, a seu ver, a licenciatura curta se encontrava "consolidada, não mais como experiência, mas como prática aceita e necessária" (p.180). O Parecer 554/72 solidificou essa modalidade de formação de professores como solução definitiva.

Estabeleceram-se ainda as distinções entre a licenciatura plena e a licenciatura curta. Elas diferiam para além da carga horária maior ou menor, não só na adequação da formação do professor para atuar em níveis diferentes de ensino, mas também nas dosagens de conhecimento, respeitando-se as fases de crescimento e o grau de maturidade dos discentes a que fossem atender. $\mathrm{Na}$ legislação educacional pós-1964 esse ponto de vista aparece sob o título de "formação progressiva do aluno", futuro professor, das atividades de ensino ou do mais abrangente para o mais específico.

Em suma, espera-se da licenciatura de $1^{\circ}$ grau que dote o professor de conteúdo e de técnicas apropriadas, que se ligam menos à linha disciplinar do que à das práticas e dos estudos coordenados em áreas, para que consiga cumprir a sua missão ...

Quanto à licenciatura plena, visarão à formação de professores, portadores de conhecimento amplo e aprofundado nas várias especializações e modalidades. É 
predominantemente monovalente e visa ao conhecimento sistematizado da Geografia, da História, da Organização Social e Política Brasileira, da Educação Moral e Cívica, e, como desdobramento desta, da área de Estudos de Problemas Brasileiros. Na licenciatura plena o ensino e a pesquisa atingem altitudes consideráveis, que as aproximam de transição com os territórios da pós-graduação, a serem, mais tarde, palmilhados pelo professor que pretenda a especialização conducente ao magistério de $3^{\circ}$ grau. (p.181)

Tratava-se, claramente, de modalidades de formação de professores com objetivos diferentes. A licenciatura curta se propunha a formar unicamente professores dotados de "conteúdos e técnicas" apropriados e habilitados unicamente ao exercício do magistério nos primeiros segmentos da escolarização. A licenciatura plena iria além, formaria o professor e contribuiria para a formação do pesquisador ou especialista em determinada área de conhecimento. O Art. $1^{\circ} \mathrm{da}$ Resolução no 8/72 estabeleceu que a formação de professores de Educação Moral e Cívica para o Ensino de $1^{\circ}$ e $2^{\circ}$ graus deveria se processar como habilitação do curso de Estudos Sociais. Previa ainda a fixação do currículo mínimo para as licenciaturas curtas e plenas em Estudos Sociais, sendo a primeira composta por 1.200 horas e a segunda, por 2.200 horas de atividades.

De acordo com essa Resolução o currículo mínimo seria composto pelas seguintes matérias: 1) História, levando-se em consideração a divisão cronológica: Antiga, Moderna, Medieval, Contemporânea e do Brasil. Importante destacar que não aparecem História da América ou História Regional como, por exemplo, História Fluminense ou Mineira; 2) Geografia, incluindo-se elementos de Geografia Física, Humana e do Brasil; 3) Fundamentos das Ciências Sociais, com ênfase no estudo da realidade social em seus aspectos sociológicos e antropológico-culturais; 4) Filosofia, com destaque para problemas fundamentais e relações com a Ética Geral e a Ética Especial e com a Religião; 5) Teoria Geral do Estado: elementos da ciência política, formas de Estado e de Governo, os Regimes Políticos, as Constituições, o Caso brasileiro; 6) Organização Social e Política do Brasil; 7) Estudos de Problemas Brasileiros; ${ }^{8}$ e, 8) Educação Física. ${ }^{9}$ Desse modo, o currículo era composto por um conjunto de disciplinas da área de Ciências Humanas e de disciplinas gerais tornadas obrigatórias no ensino superior durante as Reformas Educacionais implantadas a partir de 1964. Eram também obrigatórias as disciplinas pedagógicas estabelecidas pelo Parecer 672/69 do CFE, datado de 4 de setembro de 1969 e 
de autoria do conselheiro Valnir Chagas: 1) Psicologia da Educação (Adolescência e Aprendizagem); 2) Didática; 3) Estrutura e Funcionamento do Ensino. Exigia-se ainda a Prática de Ensino, sob forma de estágio supervisionado, das matérias objeto da habilitação profissional.

A licenciatura curta em Estudos Sociais deveria ser realizada no mínimo de 1 ano e meio e no máximo de 4 anos letivos. A Resolução no 8/72 não determinou a carga horária das disciplinas que formavam o mínimo, e no Art. $6^{\circ}$ recomendava que quando e onde houvesse condições se procedesse à ampliação da duração prevista, neste caso às 1.200 horas. A partir da publicação da Resolução os cursos já em funcionamento teriam um prazo de 90 dias para se adequarem às modificações estabelecidas pelo documento. A "proliferação de cursos de licenciatura curta" não significou o fim da licenciatura plena em História. Entretanto, apesar das reformas educacionais impostas durante o regime militar, seu currículo mínimo, aprovado em 1962, não foi alterado. Pelo contrário, vigorou até o início do século XXI, quando foram aprovadas as Diretrizes Curriculares Nacionais do curso de História.

As décadas de 1970 e 1980 se caracterizam pelo modelo de formação baseado na racionalidade técnica, em que o professor é meramente um transmissor de conhecimentos produzidos por outros. Nas palavras de Ana Maria Monteiro, a "atividade profissional consistiria na aplicação rigorosa de teorias e técnicas científicas” (Monteiro, 2002). É preciso destacar que a formação para a pesquisa apenas se iniciava no Brasil e não era a preocupação principal dos cursos de História ou dos formuladores de seus currículos. Nesse sentido, a formação do professor pautava-se no conhecimento dos conteúdos históricos (o que ensinar) e nas técnicas de transmissão desse conteúdo (como ensinar), que, não obstante, não dialogavam durante os anos de formação.

O conselheiro Valnir Chagas, em seu projeto de formação de professores, concedeu forte ênfase ao aspecto pedagógico dos cursos de licenciatura curta. Esse conselheiro defendeu que a formação pedagógica não deveria "ser algo suposto, posterior e apendicular ao conteúdo" ou uma "complementação" como, em sua opinião, vinha ocorrendo até então (Chagas, 1976, p.79). Os estudos didático-pedagógicos deveriam ser adquiridos concomitantemente com os conhecimentos do campo específico. As disciplinas da parte pedagógica deveriam ser ministradas tendo-se em vista a sua plena articulação com os conteúdos estudados pelos discentes nas disciplinas de seu curso de origem. A 
primeira proposta de ensino da UDF, formulada por Anísio Teixeira nos anos 1930, trabalhava com essa ideia. Entretanto, ambos os projetos, o de Anísio Teixeira e o de Valnir Chagas, foram derrotados e prevaleceu, por muitos anos, o modelo de formação " $3+1$ ”.

Os anos 1980 se caracterizaram pela "lenta, segura e gradual" abertura política. Com a extinção do AI-5 em 1979 a oposição ao Regime passou a ter maior margem de liberdade para se manifestar contrariamente às atitudes e políticas de governo. Os pilares da Reforma de Ensino de $1^{\circ}$ e $2^{\circ}$ graus foram revistos pela Lei ${ }^{\circ} 7.044 / 82$, publicada em 18 de outubro de 1982. Cessou a obrigatoriedade do ensino profissionalizante em nível de $2^{\circ}$ grau. No que concerne ao ensino de História, esses foram anos marcados pelos debates em prol da extinção dos cursos de Estudos Sociais em Faculdades Isoladas e Universidades, reivindicação pelo retorno da Geografia e da História nas escolas de ensino de $1^{\circ}$ grau e "pelas discussões de questões teórico-metodológicas relacionadas ao ensino e à pesquisa de história e da história como disciplina escolar, para e na formação de professores" (Mesquita; Zamboni, 2008, p.133).

O CFE insistia na manutenção dos Estudos Sociais e das licenciaturas correspondentes a essa área de estudo. Em agosto de 1980 o conselheiro Paulo Nathanael, do CFE, tornou público Parecer de sua autoria que propunha mudanças na licenciatura em Estudos Sociais. O relator promoveu uma crítica às licenciaturas curtas em Estudos Sociais, chegando a propor a sua eliminação. A única hipótese plausível de utilização dessa formação, segundo o conselheiro, seria em áreas carentes, como solução excepcional e não permanente. $\mathrm{O}$ Parecer estabelecia um novo currículo para a licenciatura em Estudos Sociais, "com habilitações plenas de História, Geografia, Educação Moral e Cívica, Organização Social e Política do Brasil”. Na prática, sugeria a extinção dos cursos de História e Geografia, que eram cursos avulsos desde meados da década de 1950. A mobilização dos historiadores foi rápida, e a Anpuh (seção paulista) apressou-se em denunciar o fato em seu Boletim Informativo:

Diante desta grave ameaça não podemos permanecer de braços cruzados. É fundamental, para viabilizar nossa resistência - que já começa atrasada - um esforço redobrado de mobilização. A Anpuh deu início a uma ampla campanha de esclarecimento da opinião pública conjuntamente com a AGB [Associação dos Geógrafos Brasileiros], para organizar os profissionais das áreas contra esta grave 
tentativa de destruir campos de conhecimentos científicos, de interferir na universidade brasileira, a quem caberia decidir sobre a natureza de sua produção científica e sobre os profissionais que deve formar, e de transformar a área vital do ensino e da educação num aglomerado de elementos a serem 'divulgados' entre os educandos. ${ }^{10}$

No documento a Associação conclamava a resistência e reconhecia o seu atraso em relação à luta contra os Estudos Sociais e as licenciaturas curtas. Tendo em vista a grave ameaça de destruição de "campos de conhecimentos científicos", era necessária organização e efetiva oposição. Diante da reação ao Parecer, expressa em certa medida nos documentos coletados por Raquel Glezer (1982) em Noticiário publicado na Revista Brasileira de História em 1982, o conselheiro acabou retirando o projeto, alegando tratar-se de um "estudo preliminar”. A professora Déa Fenelon, umas das pioneiras na oposição aos Estudos Sociais, argumenta que nos primeiros anos a luta não foi contínua. Para a autora, esta somente se mostrou "organizada e sistematizada, quando emergiram questões concretas e imediatas, tais como a regulamentação de regência de aulas, a regulamentação do registro de diplomas, a possibilidade de realização de concursos públicos para o ingresso no magistério oficial" (Fenelon, 1984, p.13).

A exclusão dos licenciados em História e Geografia do ensino de $1^{\circ}$ grau, proposta pela Portaria 790/76, atingiu diretamente os cursos universitários que formavam esses profissionais, já que o mercado de trabalho ficava restrito ao $2^{\circ}$ grau. Era um efeito cascata. A Reforma do Ensino de $1^{\circ}$ e $2^{\circ}$ graus passava a afetar em cheio as universidades e seus cursos de formação de professores. A partir daí a Anpuh tomou uma posição. Concordamos, assim, com Maria do Carmo Martins, quando salienta que é possível "identificar que a luta pela manutenção da História como disciplina escolar autônoma possuiu uma conotação fortemente política na defesa do mercado de trabalho para os graduados em História, e menos uma preocupação acadêmica sobre qual História deveria ser ensinada" (Martins, 2000, p.4). A reação à Portaria 760/76 agiu como catalisador para a reação generalizada dos historiadores contra os Estudos Sociais e as licenciaturas curtas. O começo dessa luta, sem dúvida, foi em São Paulo, embora não tenha se restringido a esse estado. A intensificação ocorreu em repúdio ao já citado Parecer de Paulo Nathanael. 
Miglio e Zamboni destacam que "diante das contínuas manifestações a Secretaria de Educação Superior (SESu/MEC) propôs o 'Diagnóstico e Avaliação dos cursos de História no Brasil'”. Para além dos cursos de História, seriam analisadas também as licenciaturas em Estudos Sociais. As autoras assinalam que foi constituído um grupo de trabalho composto por professores universitários de diferentes regiões do país e pela presidência da Anpuh. Entre os participantes encontram-se Francisco Falcón, professor da Universidade Federal Fluminense (UFF) e um dos fundadores da Associação em 1961, como relator; Déa Fenelon, docente na Universidade Estadual de Campinas (Unicamp) e presidente da Anpuh (1983-1985), coordenadora do Grupo de Consultores; Alice Piffer Canabrava, presidente da Anpuh (1981-1983), e Joana Neves, da Universidade Federal da Paraíba (UFPB). ${ }^{11}$ Déa Fenelon, em discurso proferido no XI Encontro Nacional de História (João Pessoa/1981), onde apresentou as atividades realizadas pelo Grupo, argumentou que os cursos de História estavam "simplesmente formando reprodutores de uma ciência já pronta e acabada, sem nenhum referencial teórico ou metodológico, senão aqueles das teorias já cristalizadas e estáticas" (Fenelon, 1984, p.28).

A historiadora incentivava os seus pares a assumir a responsabilidade social e política com o momento vivido, com a realidade do ensino de História e da formação de professores que se processavam no Brasil dos anos 1980. Isso significava "romper com uma maneira tradicional de conceber o conhecimento, sua produção e transmissão" e um posicionamento. Era necessária uma nova formação para o professor de História e para o historiador. Uma formação que valorizasse a prática da investigação capaz de prover o aluno da capacidade de problematizar tanto a produção intelectual quanto a própria realidade de ensino na qual o futuro professor de História iria atuar. A pesquisa não deveria estar dissociada do ensino nos cursos de formação de professores. O saber precisava ser questionado, bem como o contexto histórico em que o docente se insere. Assim, Fenelon argumentava que o profissional de História deveria ser "capaz de transmitir uma História viva e não morta, ensinar uma História na qual as pessoas possam se reconhecer e se identificar, porque para nós a História é uma experiência que deve ser também concretizada no cotidiano, porque é a partir dela que construiremos o hoje e o futuro" (p.31).

A questão estava posta no cenário educacional e a licenciatura curta em Estudos Sociais começava a entrar em decadência, em decorrência da forte 
oposição. Durante o XII Simpósio da Anpuh, realizado em Salvador, em 1984, aprovou-se uma moção pela extinção dos Estudos Sociais baseada nos seguintes termos:

a) pela extinção das licenciaturas curtas e plenas de Estudos Sociais e suas habilitações no ensino de $3^{\circ}$ grau;

b) pela redistribuição do conteúdo e da carga horária de OSPB entre as disciplinas de Geografia e História;

c) pela substituição de Estudos Sociais por Geografia e História, nas quatro séries finais do ensino de $1^{\circ}$ grau, em qualquer condição que seja ministrada e, consequentemente, a necessária ampliação da carga horária. (Fenelon, 1984, p.19)

Ao longo dos anos 1980, as faculdades e universidades que ministravam as licenciaturas curtas em Estudos Sociais passaram a solicitar a plenificação desses cursos e sua transformação em ciclo básico das licenciaturas plenas em História e Geografia. As licenciaturas curtas foram extintas definitivamente com a promulgação da Lei de Diretrizes e Bases da Educação em 20 de dezembro de 1996. De acordo com o Art. 62: "A formação de docentes para atuar na educação básica far-se-á em nível superior, em curso de licenciatura, de graduação plena, em universidades e institutos superiores de educação, admitida, como formação mínima para o exercício do magistério na educação infantil e nas primeiras séries do ensino fundamental, a oferecida em nível médio, na modalidade Normal" (Brasil, 1996).

Nos anos 1990, período em que o processo de redemocratização se consolidava, novas reformas educacionais foram implementadas. Da Lei de Diretrizes e Bases de 1996 emergiram outros documentos, com o intuito de garantir a reforma educacional, tais como: as Diretrizes Curriculares para a educação infantil, o ensino fundamental e médio; as Diretrizes Curriculares para os cursos de nível superior, e os Parâmetros Curriculares Nacionais (PCNs). De acordo com a historiografia educacional, "desde a década de 1990, vêm se configurando, no Brasil, discussões acerca da formação de professores reflexivos, investigadores de sua prática”. Esse professor não é mais um simples técnico ou reprodutor de conhecimentos, mas é "capaz de investigar os problemas que se colocam no cotidiano escolar", mobilizar recursos, 
procedimentos e conhecimento para a sua superação e avaliar a adequação de suas escolhas e saberes (Caimi, 2001, p.38-39).

\section{A FormaÇÃo dos PROFESSORES DE História no SÉCUlo XXI: as Diretrizes Curriculares Nacionais ${ }^{12}$}

Na última década os cursos de formação de professores foram objeto de inúmeros documentos normatizadores. Em dezembro de 1997 a Secretaria de Ensino Superior do Ministério da Educação (SESu/MEC) convocou, por edital, as instituições de ensino superior (IES) a apresentarem sugestões para a elaboração das Diretrizes Curriculares para os cursos de graduação. No ano seguinte, entre junho e novembro, uma comissão de especialistas composta pelos professores Ciro Flamarion Cardoso, Elizabeth Cancelli e Luzia Margareth Rago, designada pelo Ministério da Educação, e a direção da Associação Nacional de História (Anpuh) produziram o documento das Diretrizes para os cursos de História. As Diretrizes Curriculares Nacionais dos cursos de História foram aprovadas pelo Conselho Nacional de Educação mediante o Parecer CNE/CES 492 de 3 de abril de 2001 e fixadas pela Resolução CNE/CES $\mathrm{n}^{\circ} 13$, de 13 de março de 2002.

Uma das finalidades principais do documento é substituir o currículo mínimo estabelecido em 1962. A substituição se impunha pelas transformações ocorridas no cenário educacional brasileiro. No início da década de 1960, os cursos de História começavam a se expandir significativamente pelo país e as atividades de pesquisa ainda engatinhavam, sobretudo em grandes centros como São Paulo e Rio de Janeiro. Na década seguinte, a pós-graduação começou a ser efetivamente implantada no Brasil. Os autores das Diretrizes argumentam que nesses anos foram dados passos muito importantes para a profissionalização dos historiadores. Da mesma forma, ocorreram significativas mudanças teóricas e metodológicas no campo da História, o que tornava cada vez mais o currículo mínimo de 1962 obsoleto e uma 'camisa de força'. A área da atuação dos historiadores também se alterou desde os anos 1960. Esses profissionais não se dedicam mais apenas aos ensinos fundamental, médio e superior, mas atuam em centros de pesquisa e museus (citando apenas duas das possibilidades) e manejam diferentes tipos de linguagem para além da textual. Assim, o graduado em História deverá estar apto 
ao exercício de trabalho do historiador, em todas as suas dimensões, o que supõe pleno domínio da natureza do conhecimento histórico e das práticas essenciais de sua produção e difusão. Atendidas essas exigências básicas e conforme as possibilidades, necessidades e interesses das IES, com formação complementar e interdisciplinar, o profissional estará em condições de suprir demandas sociais relativas ao seu campo de conhecimento (magistério em todos os graus, preservação do patrimônio, assessorias a entidades públicas e privadas, nos setores culturais, artísticos, turísticos etc.).

O texto enfatiza a formação de um profissional qualificado a exercer atividades de ensino, pesquisa e extensão. Estes são aspectos que se inter-relacionam, ou deveriam, na formação do historiador e professor de História. É um rompimento com o que propôs a política de formação de professores defendida pelo CFE nos anos 1970 e 1980, que distinguia as formações do professor e do pesquisador. Aquele que provinha da licenciatura curta era professor e não tinha formação para ser nada mais. Entretanto, as Diretrizes apresentam como foco principal a formação do historiador. A formação do professor de História é quase uma consequência, ou seja, o professor se forma sobre o domínio do instrumental teórico-metodológico do historiador. As Diretrizes expõem sete habilidades e competências que devem ser trabalhadas na formação dos discentes dos cursos de História. Apenas duas delas se referem diretamente às licenciaturas.

\section{A) Gerais}

a) Dominar as diferentes concepções metodológicas que referenciam a construção de categorias para a investigação e a análise das relações sóciohistóricas;

b) Problematizar, nas múltiplas dimensões das experiências dos sujeitos históricos, a constituição de diferentes relações de tempo e espaço;

c) Conhecer as informações básicas referentes às diferentes épocas históricas nas várias tradições civilizatórias, assim como sua inter-relação;

d) Transitar pelas fronteiras entre a História e outras áreas do conhecimento;

e) Desenvolver a pesquisa, a produção do conhecimento e sua difusão não só no âmbito acadêmico, mas também em instituições de ensino, museus, em órgãos de preservação de documentos e no desenvolvimento de políticas e projetos de gestão do patrimônio cultural;

f) Ter competência na utilização da informática. 
B) Específicas para licenciatura

a) Domínio dos conteúdos básicos que são objeto de ensino - aprendizagem no ensino fundamental e médio;

b) Domínio dos métodos e técnicas pedagógicos que permitem a transmissão do conhecimento para os diferentes níveis de ensino.

As competências e habilidades apresentam tópicos antigos e novos necessários para a formação dos alunos que cursam História. Desde a década de 1980 novas concepções metodológicas são discutidas pelos historiadores. Problematizar essas múltiplas concepções, as diferentes experiências dos sujeitos históricos e as relações espaço-tempo são aspectos inerentes ao ofício do historiador, bem como conhecer e analisar contextos históricos diversos. A pesquisa surge como eixo principal na formação desse aluno e deve ser realizada durante os anos de graduação e mesmo após o término desse tempo de estudo. Entretanto, não aparece no corpo do texto nenhuma relação entre os cursos superiores de História e as escolas básicas, o destino de boa parte dos egressos desses cursos. Nas especificidades da licenciatura aparece uma dupla preocupação: 'o que ensinar' (domínio básico dos conteúdos históricos) e 'como ensinar' (métodos e técnicas de ensino). Uma novidade das Diretrizes, em relação ao Currículo Mínimo de 1962, é a obrigatoriedade de desenvolvimento das atividades de prática de ensino no interior dos cursos de História e sob responsabilidade destes. Durante o processo de institucionalização dos cursos de História e nas décadas seguintes a formação pedagógica se processava distanciada da formação dita 'específica' ou 'de conteúdo' e ocorria nas Faculdades ou Departamentos de Educação. Na letra da Diretriz, conteúdo e prática pedagógica devem estar associados de forma sistemática e permanente.

A formulação dos conteúdos curriculares não inovou, significativamente em relação ao Currículo Mínimo anterior, mas manteve a mesma flexibilidade. Os formuladores das Diretrizes os dividem em três pontos: 1) conteúdos históricos/historiográficos e as práticas de pesquisa, sob diferentes matizes e concepções, que tratam da História em seus grandes marcos espaço-temporais; 2) conteúdos que permitam a interlocução entre a História e as outras áreas do conhecimento; 3) conteúdos complementares. Para as licenciaturas devem "ser incluídos os conteúdos definidos para a educação básica, as didáticas próprias 
de cada conteúdo e as pesquisas que as embasam". A criação de disciplinas específicas ao ensino da História e a inclusão das pesquisas sobre essa temática como um conteúdo necessário à constituição das licenciaturas em História são uma grande vitória de um campo de pesquisa que ainda luta pela sua consolidação no cenário acadêmico.

A legislação apresenta uma concepção de formação do professor de História que não se preocupa apenas com o domínio do conteúdo histórico, mas busca diálogos com outras áreas. Mais ainda, defende a formação do professor-pesquisador, um produtor de saberes e conhecimento, e um rompimento com a ideia de professor meramente transmissor de conhecimentos produzidos por outros. As licenciaturas são regidas, ainda, pelas Diretrizes Curriculares Nacionais para a Formação dos Professores da Educação Básica. De acordo com a Resolução CNP/CP 1, de 18 de fevereiro de 2002,

As Diretrizes Curriculares Nacionais para a Formação de Professores da Educação Básica, em nível superior, em curso de licenciatura, de graduação plena, constituem-se de um conjunto de princípios, fundamentos e procedimentos a serem observados na organização institucional e curricular de cada estabelecimento de ensino e aplicam-se a todas as etapas e modalidades da educação básica.

Alguns princípios devem guiar a formação do professor do ensino básico. A pesquisa, com foco no processo de ensino e aprendizagem, aparece como um desses princípios, já que, segundo o documento, "ensinar requer, tanto dispor de conhecimentos e mobilizá-los para a ação, como compreender o processo de construção do conhecimento". Na formação do professor devem ser trabalhadas algumas competências, tais como: compreensão do papel da escola na sociedade, domínio dos conteúdos a serem socializados e dos conhecimentos pedagógicos e "conhecimento de processos de investigação que possibilitem o aperfeiçoamento da prática pedagógica”, entre outras. No que concerne aos conhecimentos necessários à constituição das diferentes competências são enumerados elementos que possibilitem ao futuro professor a inserção no debate sobre a docência e no cenário contemporâneo mais amplo. Isso implica conhecimento do conteúdo objeto de ensino, sobre o público alvo objeto das atividades docentes, a dimensão cultural, social, política e econômica da educação. 
FORMAÇÃO DO PROFESSOR DE HISTÓRIA:

DIÁlOGOS CONTEMPORÂNEOS

Todo professor tem de conciliar pelo menos duas vocações em seu coração: a da especialização, que adquire (com não pouco esforço) durante seus estudos, e a de ensinar, a pedagógica, sem a qual (pode-se supor) não conseguirá ter sucesso no ensino de sua especialidade.

John Rüsen

O ideal seria que todos fôssemos ótimos professores e excelentes pesquisadores. Isso é impossível.

Carlos Fico

A discussão no que concerne à relação entre formação inicial e prática docente e à composição dos saberes docentes dos professores de História do ensino básico não é recente no Brasil, remontando aos anos 1980 e 1990. O historiador mineiro Luiz Carlos Villalta analisa, em artigo publicado na Revista Brasileira de História no início dos anos 1990, entre outros aspectos, o processo de (não) articulação entre teoria e prática nos cursos de formação de professores de História. Em um primeiro momento o autor estabelece uma distinção entre o que denomina como 'professor ideal' e 'professor real'. Em seguida analisa "de que modo a formação do professor [de história] com seus problemas teóricos e práticos e a dicotomia entre teoria e prática nela verificadas contribui para um distanciamento" entre a imagem docente idealizada pelos educadores e o professor existente na realidade. De acordo com o professor,

Na maioria dos cursos de Graduação em História, as discussões teóricas, metodológicas e historiográficas restringem-se ao âmbito das disciplinas denominadas "Introdução aos Estudos Históricos", "Metodologia da História", "Historiografia" e “Teoria da História”. As demais disciplinas passam ao largo dessas discussões, como se seu papel fosse, exclusivamente, transmitir o 'conhecimento' produzido sobre determinados temas, não refletindo sobre a diversidade existente no interior deste conhecimento, seus fundamentos teóricos e metodológicos. (Villalta, 1992-1993)

Ainda segundo o autor, essa 'pobreza teórica' não é compensada por uma 'vivência prática' intensa ou mesmo satisfatória. Outro problema apontado se refere à dicotomia que se estabelece, nos cursos de História, entre as 
'disciplinas de conteúdo', ou seja, as disciplinas específicas da História e da Historiografia, e as de 'instrumentação pedagógica', cursadas nas Faculdades de Educação. Dessa forma, consolida-se uma falta de articulação entre os historiadores ('especialistas do conteúdo') e os pedagogos. Nos próprios Departamentos de História inexiste a articulação entre as disciplinas de conteúdo formal (História do Brasil, da América etc.) e as disciplinas de Prática de Ensino de História. Enfim, o historiador argumenta que "a essa precariedade e insuficiência da teoria ... soma-se a colocação da 'prática' em segundo plano" (Villalta, 1992-1993, p.227-229).

A necessidade de formação do professor/pesquisador e da superação da dicotomia entre teoria e prática na formação de professores está posta, no meio acadêmico brasileiro, desde pelo menos a década de 1980. Os cursos de formação de professores, muito além de formarem pessoas capacitadas a ministrar determinados conteúdos, devem ser capazes de formar professores que produzam conhecimento, reflitam sobre suas práticas e pesquisem. Portanto, a concepção de professores se alterou profundamente nos últimos anos, sobretudo a partir da década de 1990. Entretanto, essa formação não está isenta de problemas. Em artigo recente o historiador fluminense Carlos Fico refletiu sobre sua formação, no curso de História dos anos 1980, e definiu um currículo ideal para tais cursos. Segundo ele, é comum que os cursos de graduação em História privilegiem a formação do pesquisador. Assim, é frequente que

a formação pedagógica seja uma responsabilidade específica das Faculdades de Educação. Quando eu fiz a graduação, havia o curso de bacharelado, que todos fazíamos, e as disciplinas de Educação, que deviam ser cursadas por quem quisesse fazer a licenciatura. Para tornar-se bacharel em História também era preciso redigir a monografia de bacharelado e, no caso da licenciatura, além das disciplinas da Educação, havia a necessidade de se estagiar em alguma escola. Creio que, na essência, isso pouco mudou.

No meu currículo ideal para um curso de graduação em História, as disciplinas deveriam basear-se em um tripé que amparasse (a) o debate historiográfico, (b) as reflexões teórico-conceituais pertinentes ao tema e (c) o debate sobre o ensino das questões em pauta. Ou seja, para mim não deveriam existir as tais disciplinas de formação pedagógica e, muito menos, disciplinas obrigatórias como Metodologia da História. Todo professor universitário de História deveria ser capaz de debater o ensino e os aspectos teórico-metodológicos relacionados 
à sua disciplina. Claro que isso não impediria a oferta de eletivas específicas sobre teoria, metodologia e ensino. (Fico, s.d.)

A experiência de formação de Carlos Fico se caracteriza, em grande parte, pelas questões apontadas por Villalta em seu trabalho: distanciamento entre as disciplinas pedagógicas e as disciplinas ditas específicas ou de conhecimento histórico, e formação nas licenciaturas baseada em técnicas de ensino. Ana Maria Monteiro, em estudo já clássico sobre formação de professores e os saberes docentes, argumenta que esse paradigma "trabalhava com a concepção de professor como instrumento de transmissão de saberes produzidos por outros", fortalecendo a dicotomia entre professor e pesquisador e gerando a falsa ideia de que a prática docente se constrói, exclusivamente, com a aplicação de teorias obtidas nos cursos de formação de professores (Monteiro, 2002, p.122). No entanto, os cursos de licenciatura plena em História não pararam no tempo e não mais se limitam a um conjunto de disciplinas que devam ser cursadas como mera formalidade, ou uma aula que deva ser ministrada, em alguma escola, sem preparo algum.

Tendo como base a sua formação inicial e certamente a sua vivência enquanto professor universitário, Carlos Fico estabelece um modelo de formação de professores. Um currículo ideal construído mediante debate historiográfico, discussões teórico-conceituais pertinentes à História como ciência e "o debate sobre o ensino das questões em pauta”. Essa concepção se aproxima do que defendem as Diretrizes Curriculares Nacionais para os cursos de História. O historiador vai além, argumenta que "todo professor universitário de História deveria ser capaz de debater o ensino e os aspectos teórico-metodológicos relacionados à sua disciplina". Entretanto, isso, infelizmente, ainda não acontece na maioria dos cursos de licenciatura em História. Os professores das disciplinas ditas específicas - por exemplo, História do Brasil ou História da América -, salvo raras exceções, limitam-se aos conteúdos e teóricos de suas disciplinas, sem promover a articulação entre esses aspectos e o ensino. O fim das disciplinas pedagógicas, sejam elas ministradas pelas Faculdades de Educação ou pelos Departamentos e Faculdades de História, não resolvem a questão.

Propostas recentes, como as realizadas pela Universidade Federal de Santa Catarina (UFSC) e pela Universidade do Estado de Santa Catarina (Udesc), 
demonstram a importância das disciplinas pedagógicas, das Práticas de Ensino e do Estágio Supervisionado, e também das disciplinas de ensino de História, como os Laboratórios de Ensino de História, na formação dos professores de História. Essas disciplinas devem dialogar com as outras que compõem os currículos. São novos debates. Cristiani Bereta da Silva e Claricia Otto, no prefácio do livro em que apresentam as experimentações desenvolvidas no estágio supervisionado na UFSC e da Udesc, destacam avanços e recuos, permanências e rupturas na formação do professor neste início de século (Silva; Otto, 2011, p.11-19). Vivenciamos um processo de construção de uma nova concepção de formação do professor de História. De acordo com a professora Selva Guimarães Fonseca,

O historiador-educador ou o professor de História é alguém que domina não apenas os métodos de construção do conhecimento histórico, mas um conjunto de saberes e mecanismos que possibilitam a socialização deste conhecimento. "Saber alguma coisa não é mais suficiente para o ensino, é preciso saber ensinar." (Fonseca, 2006, p.23)

Perspectiva semelhante defende a professora Luciana Rossato. Para a autora,

Aprender História não é somente acumular uma sequência de fatos e processos passados. $\mathrm{O}$ aprendizado histórico envolve apropriar-se de aspectos da epistemologia do fazer histórico, entre as quais a compreensão de conceitos do tempo, a identificação das evidências e de que estas são incompletas e limitadas como são limitadas e provisórias as explicações históricas. A partir dessa perspectiva, ensinar história não se restringe a ensinar narrativas históricas elaboradas pelos historiadores e organizadas em uma lista de conteúdos previamente definidos. Ensinar história é algo mais complexo, é ensinar a capacidade de pensar historicamente. Para isso, além dos conteúdos, devem ser desenvolvidas habilidades cognitivas que visem possibilitar que os indivíduos possam conhecer e explicar o mundo a partir das ferramentas próprias do saber histórico. (Rossato, 2011, p.89-90)

Assim, a formação do professor de História deve, igualmente, zelar pela construção do conhecimento histórico e pelas formas pelas quais esses conhecimentos serão socializados pelo futuro professor. É consenso na literatura educacional que os saberes dos professores são oriundos de diferentes fontes 
e construídos em diferentes períodos da trajetória profissional e de vida dos professores de História. ${ }^{13}$ Entretanto, é na formação inicial "que os saberes históricos e pedagógicos são mobilizados, problematizados, sistematizados e incorporados à experiência de construção do saber docente" (Fonseca, 2010). Nesse percurso, aprendemos a conciliar duas vocações que não devem estar dissociadas em nossa formação inicial e futura prática docente: o ensino e a pesquisa. Pesquisa como parte inerente das atividades de ensino. Esse é o desafio principal da formação do professor de História no século XXI e a questão maior que devemos enfrentar.

\section{CONSIDERAÇÕES FINAIS}

A constituição de cursos de formação do professor de História em universidades no Brasil é recente, o que não significa que propor uma periodização para a escrita da sua História seja uma tarefa fácil. O historiador, em seu ofício, seleciona tanto o material de análise (as fontes) quanto os referenciais teóricos com os quais irá dialogar na produção de seu trabalho. Essas seleções ocorrem, sobretudo, em função de questões preestabelecidas e do contexto (social e de escrita) em que o historiador está inserido. Nesse sentido, optamos por uma análise das diferentes legislações normatizadoras. De acordo com a historiadora Thais Nivia de Lima e Fonseca,

Dos historiadores espera-se que conheçam bem a historiografia, os pressupostos teórico-metodológicos que orientam seu trabalho, as técnicas de investigação, os procedimentos para o tratamento das fontes de pesquisa. Além de tudo isso, daqueles que são também professores de História, espera-se que conheçam os conteúdos, as práticas pedagógicas e os procedimentos didáticos. No entanto, não é usual esperar que eles conheçam, também, a história da disciplina que pesquisam ou que ensinam. Seria, porém, desejável que isso ocorresse. (Fonseca, 2011, p.7)

De fato, apesar do crescimento significativo das pesquisas em torno do Ensino de História e sua História, existem desconhecimentos em relação a esse campo. Muitos professores de História e historiadores têm certas resistências quando esse é o tema. Trata-se de um campo de pesquisa consolidado e com rica produção. Entretanto, muitos alunos das licenciaturas e bacharelados em História desconhecem a história de seu próprio curso e da disciplina que lhes 
cabe ensinar. Os trabalhos sobre a história da formação dos professores de História e a institucionalização desses cursos ainda são escassos ou pouco divulgados. Durante investigações desenvolvidas no curso de Mestrado em História Social, deparamos com uma quantidade de trabalho pequena, porém de qualidade significativa sobre esses objetos e com uma legislação normatizadora sobre a formação do docente de História pouco explorada pelos historiadores. Daí surgiu a ideia da periodização proposta em grandes marcos. É bem verdade que outros caminhos são possíveis. Propomos um diálogo, uma reflexão baseada em diferentes matrizes de interpretação e vasta bibliografia temática.

François Hartog adverte que "escrever é também propor uma resposta à questão de como circular entre passado, presente e também futuro" (Hartog, 1996). Escrever sobre a formação do professor de História é, consequentemente, dialogar com estes três tempos: a história desta formação, a formação atual e as perspectivas futuras. De diferentes formas, todos nós, professores de História, estamos envolvidos nessa formação e por essa formação, e contribuímos para a sua escrita. Somos agentes desse processo. A formação do professor de História está em constante movimento. Os próximos passos estão sendo pensados, trilhados. É outra conversa...

\section{REFERÊNCIAS}

AGUIAR, José Márcio de (Org.) CFE - Pareceres Básicos: Reforma - Ensino de $1^{\circ}$ e $2^{\circ}$ graus. Brasília: MAI Ed., 1975.

AGUIAR, Letícia Carneiro. A formação de professores catarinenses na década de 1960 e 1970: entre proposições e realizações. In: JORNADA DO HISTEDBR, IX, 2010, Belém-PA. Trabalhos Completos... Campinas (SP): Histedbr, 2010. p.1-2.

AYRES, Ana Cléa B. M. Tensão entre matrizes: um estudo a partir do Curso de Ciências Biológicas da Faculdade de Formação de Professores/UERJ. 183 f. Tese (Doutorado em Educação) - Faculdade de Educação, UFF. Niterói (RJ), 2005.

AZEVEDO, Fernando de [1932]. A reconstrução educacional do Brasil. Manifesto dos Pioneiros da Educação Nova. In: GONDRA, José G.; MAGALDI, Ana Maria (Org.) A reorganização do campo educacional no Brasil: manifestações, manifestos, manifestantes. Rio de Janeiro: 7Letras, 2003.

BEZERRA, Francisco Chaves. O ensino superior de História na Paraíba (1952-1974): 
aspectos acadêmicos e institucionais. 140 f. Dissertação (Mestrado em História)

- Universidade Federal da Paraíba. João Pessoa, 2007.

BORGES, Cecília. O professor da Educação Básica de $5^{\mathrm{a}}$ a $6^{\mathrm{a}}$ série e seus saberes profissionais. 256 f. Tese (Doutorado em Educação) - Departamento de Educação, PUC/RJ. Rio de Janeiro, 2002.

BRASIL. Diretrizes Curriculares Nacionais para a Formação de Professores da Educação Básica, em nível superior, curso de licenciatura, de graduação plena. Disponível em: http://portal.mec.gov.br/index.php?option=com_content\& view=article\&id=12991; Acesso em: 1 dez. 2012.

BRASIL. Parecer CNE/CES no 492, de 3 abr. 2001. Aprova as Diretrizes Curriculares Nacionais dos cursos de Arquivologia, Biblioteconomia, Ciências Sociais - Antropologia, Ciência Política e Sociologia, Comunicação Social, Filosofia, Geografia, História, Letras, Museologia e Serviço Social. Disponível em: http://portal.mec. gov.br/index.php?option=com_content\&view=article\&id=12991; Acesso em: 1 dez. 2012.

BRASIL. Resolução CNE/CES no 13, de 13 mar. 2002. Estabelece as Diretrizes Curriculares para os cursos de História. Disponível em: http://portal.mec.gov.br/index. php?option=com_content\&view=article\&id=12991; Acesso em: 1 dez. 2012.

CAIMI, Flávia Eloísa. Conversas e Controvérsias: o ensino de História no Brasil (19801998). Passo Fundo (RS): Ed. Universitária UFP, 2001.

CANDAU, Vera. Novos rumos da Licenciatura. Brasília: Inep, 1987.

CHAGAS, Valnir. Formação do magistério: novo sistema. São Paulo: Atlas, 1976.

CIAMPI, Helenice. O professor de História e a produção dos saberes escolares: $\mathrm{O}$ Lugar da Memória. In: FERREIRA, Antonio C; BEZERRA, Holien G; LUCCA, Tania Regina de (Org.) O Historiador e o seu tempo. São Paulo: Ed. Unesp, 2008. p.203-221.

FENELON, Déa. A formação do profissional de História e a realidade do ensino. Cadernos Cedes, Campinas (SP), n.8, p.24-31, 1983.

FENELON, Déa. A questão de Estudos Sociais. In: ZAMBONI, Ernesta (Org.) A prática do ensino de história. São Paulo: Vozes; Cedes, 1984. p.13.

FERREIRA, Marieta de Moraes. A trajetória de Henri Hauser: um elo entre gerações. In: NEVES, Lúcia Maria B. P. das; GUIMARÃES, Lúcia Maria P.; GONÇALVES, Márcia de A.; GONTIJO, Rebeca (Org.) Estudos de Historiografia Brasileira. Rio de Janeiro: Ed. FGV, 2011. p.237-259.

. Notas sobre a Institucionalização dos Cursos Universitários de História no Rio de Janeiro. In: GUIMARÃES, Manoel Luiz Salgado (Org.) Estudos sobre a Escrita da História, Rio de Janeiro: 7Letras, 2006.

. O ensino da História na Faculdade Nacional de Filosofia da Universidade 
do Brasil. História, Ciências, Saúde - Manguinhos, Rio de Janeiro, v.19, n.2, p.611636, abr.-jun. 2012.

FERREIRA, Marieta de Moraes. Os professores franceses e o ensino da História no Rio de Janeiro nos anos 30. In: MAIO, Marcos Chor; VILLAS BÔAS, Glaucia (Org.) Ideais de Modernidade e Sociologia no Brasil: ensaios sobre Luiz de Aguiar Costa Pinto. Porto Alegre: Ed. UFRGS, 1999. v.1, p.277-299.

FICO, Carlos. A carreira do professor de História. Disponível em: www.brasilrecente. com/2011/07/carreira-do-professor-de-historia.html; Acesso em: 1 dez. 2012.

FONSECA, Selva Guimarães. Caminhos da História ensinada. 11.ed. Campinas (SP): Papirus, 2010.

. Formação de professores de História: reflexões sobre um campo de pesquisa (1987-2009). Cadernos de História da Educação, Belo Horizonte, v.11, n.1, p.285303, jan.-jun. 2012. 2006.

Ser professor no Brasil: História Oral de Vida. 3.ed. Campinas (SP): Papirus,

.; COUTO, Regina Célia do. A formação de professores de História no Brasil: perspectivas desafiadoras do nosso tempo. In: FONSECA, Selva; ZAMBONI, Ernesta. Espaços de formação do professor de História. Campinas (SP): Papirus, 2008. p.101-130.

FONSECA, Thais Nivia de Lima e. História \& Ensino de História. 3.ed. Belo Horizonte: Autêntica, 2011. p.7.

GLEZER, Raquel. Estudos Sociais: um problema contínuo. Revista Brasileira de História, São Paulo, v.2, n.3, p.117-149, mar. 1982.

HARTOG, François. Tempo e História: “como escrever a História da França hoje?”. História Social, Campinas (SP), n.3, p.127-154, 1996.

LINHARES, Maria Yedda Leite. O lugar das disciplinas pedagógicas no curso de História. In: SIMPÓSIO DE PROFESSORES DE HISTÓRIA DO ENSINO SUPERIOR, 1., 1961, Marília (SP). Anais... São Paulo: FFCL-USP, 1962. p.161-187.

LOPES, Sônia de Castro. A formação do professor de História na Universidade do Distrito Federal (1935-1939). Educação em Foco, Juiz de Fora, v.15, n.2, p.111-134, set. 2010-fev. 2011.

. Um modelo autônomo e integrador de formação docente: a breve experiência da Universidade do Distrito Federal (1935-1939). Revista Contemporânea de Educação, Rio de Janeiro, v.3, n.5, p.147-164, jan.-jun. 2008.

MACHADO, Mônica Sampaio. A implantação da Geografia universitária no Rio de Janeiro. Scripta Nova (Revista Eletrônica de Geografia e Ciencias Sociales), n.69, p.1-18, ago. 2000.

MARTINS, Maria do Carmo. A História prescrita e disciplinada nos currículos escola- 
res? Quem legitima estes saberes. 263 f. Tese (Doutorado em Educação) - Faculdade de Educação, Universidade Estadual de Campinas (Unicamp). Campinas (SP), 2000.

MESQUITA, Ilka Miglio. Memórias/identidades em relação ao ensino e formação de professores de História: diálogos com fóruns acadêmicos nacionais. $269 \mathrm{f}$. Tese (Doutorado em Educação) - Faculdade de Educação, Universidade Estadual de Campinas (Unicamp). Campinas (SP), 2008.

.; ZAMBONI, Ernesta. A formação de professores na trajetória histórica da Associação Nacional de História (Anpuh). In: FONSECA, Selva; ZAMBONI, Ernesta. Espaços de formação do professor de História. Campinas (SP): Papirus, 2008. p.130-162.

MONTEIRO, Ana Maria. Ensino de História: entre saberes e práticas. $256 \mathrm{f}$. Tese (Doutorado em Educação) - Departamento de Educação, PUC-Rio. Rio de Janeiro, 2002.

NADAI, Elza. O ensino de História no Brasil: trajetória e perspectiva. Revista Brasileira de História, São Paulo, v.13, n.25/26, p.143-165, set. 1992-ago. 1993.

. O projeto republicano de educação superior e a Universidade de São Paulo. Revista de História, São Paulo, n.115, p.3-16, jul.-dez. 1983.

NASCIMENTO, Thiago Rodrigues. Licenciatura curta em Estudos Sociais no Brasil: sua trajetória na Faculdade de Formação de Professores de São Gonçalo/RJ (19731987). 236 f. Dissertação (Mestrado em História Social) - Faculdade de Formação de Professores de São Gonçalo, Universidade do Estado do Rio de Janeiro (Uerj). São Gonçalo (RJ), 2012.

NATHANAEL, Paulo. Parecer 554/72 do Conselho Federal de Educação. Currículo Mínimo para habilitação em Educação Moral e Cívica. Documenta, n.139, jun. 1972.

RICCI, Cláudia Sapag. A formação do professor e o ensino de História: espaços e dimensões de práticas educativas (Belo Horizonte, 1980/2003). 327 f. Tese (Doutorado em História Social) - Universidade de São Paulo. São Paulo, 2003.

ROIZ, Diogo da Silva. A institucionalização do ensino universitário de Geografia e História na Faculdade de Filosofia, Ciências e Letras da Universidade de São Paulo, entre 1934 e 1956. Agora, Santa Cruz do Sul (RS), v.13, n.1, p.65-104, jan.-jun. 2007.

ROSSATO, Luciana. Formação docente inicial no curso de História na Universidade do Estado de Santa Catarina: experiências e reflexões sobre o ensino de História. In: SILVA, Cristiani Bereta et al. (Org.) Experiências de ensino de História no Estádio Supervisionado. Florianópolis: Ed. Udesc, 2011. p.89-90.

SILVA, Cristiani Bereta; OTTO, Claricia. Ensaiar práticas e transforma-se pela expe- 
riência. In: SILVA, Cristiani Bereta et al. (Org.) Experiências de ensino de História no Estádio Supervisionado. Florianópolis: Ed. Udesc, 2011. p.11-19.

SUCUPIRA, Newton. Parecer 106/66 do Conselho Federal de Educação. Currículo mínimo de Licenciatura em Estudos Sociais. Documenta, Rio de Janeiro, n.46, 1966.

TARDIF, Maurice. Saberes Docentes e Formação Profissional. Petrópolis (RJ): Vozes, 2002.

VV. AA. Anais do I Simpósio dos Professores de História do Ensino Superior em 1961. Marília: APUH, 1962. Disponível em: http://anpuh.org/anais/; Acesso em: 19 nov. 2012.

VILLALTA, Luiz Carlos. Dilemas da relação teoria e prática na formação do professor de História: alternativas em perspectiva. Revista Brasileira de História, São Paulo, v.13, n.25/26 p.223-232, set. 1992-ago. 1993.

\section{NOTAS}

${ }^{1}$ Anunciado na IV Conferência Nacional de Educação realizada, no Rio de Janeiro, em dezembro de 1931 pela Associação Brasileira de Educação (ABE) o Manifesto dos Pioneiros da Educação Nova foi redigido por Fernando de Azevedo e publicado pela primeira vez em 1932. Contou com 26 signatários e apresentou um programa de reforma educacional pautado em alguns princípios básicos: a defesa da escola pública, leiga, única, obrigatória e gratuita. A educação superior e a formação de professores receberam uma grande atenção no documento. Cf. AZEVEDO, 2003.

${ }_{2}^{2}$ Para uma análise aprofundada destas modificações e da perspectiva de ensino defendida por Henry Hauser cf., respectivamente, FERREIRA, 2011, p.237-259; e LOPES, 2010-2011.

${ }^{3}$ O CFE foi criado através do Decreto $\mathrm{n}^{\circ} 51.404$, de 5 fev. 1962. Martins o define enquanto "órgão público normatizador [cujas] decisões são tornadas públicas por meio de documentos relativos aos processos instaurados internamente. Tais processos são distribuídos para estudos e pareceres dos conselheiros, que posteriormente os apresentam para discussão da Câmara de Ensino a que estiver vinculado. Depois de aprovado na Câmara, o parecer do relator é enviado para conhecimento dos outros conselheiros, na Plenária Executiva (Pleno). Somente após aprovação no Pleno é que os resultados podem ser divulgados". Ainda segundo a autora no período entre os anos 1970-1980, o CFE dividia-se em duas Câmaras setoriais: A Câmara de Ensino Superior (CESu) e a Câmara de Ensino de $1^{\circ}$ e $2^{\circ}$ graus. Para uma compreensão acerca da estruturação e composição do CFE no período das Reformas Educacionais. cf. MARTINS, 2000, p.21.

${ }^{4}$ A Associação Nacional de História, através do Projeto Memória Anpuh-Brasil, digitalizou os Anais dos encontros nacionais realizados desde 1961. Neste artigo utilizamos: VV. AA., 1962. 
${ }^{5}$ Cf. LINHARES, 1962, p.161-187. Objetivando a fluidez do texto, nos limitaremos a uma única nota referente a esta indicação bibliográfica, indicando a página em que a citação foi extraída no corpo do texto.

${ }^{6}$ O Decreto-Lei no 869/69, de 12 set. 1969, assinado pela Junta Militar, que substituiu o presidente Costa e Silva, e pelo ministro da Educação Tarso Dutra estabeleceu em seu Art. $1^{\circ}$ Educação Moral e Cívica em caráter obrigatório como disciplina e também como prática educativa nas escolas de todos os graus e modalidades do país. No ensino superior seria ensinado sob a forma de Estudos de Problemas Brasileiros, devendo ser ministrado em no mínimo dois semestres. No $7^{\circ}$ Art. estipulou que a formação dos professores e orientadores deveria se processar em nível universitário e nos cursos normais. Este mesmo documento tornou obrigatório o ensino de Organização Social e Política do Brasil nos currículos escolares do país. O Decreto n 68.065, de 14 jan. 1971, regulamentou o Decreto-Lei de 1969 estabelecendo em seu Art. 35 que a formação em Escolas Normais habilitaria ao ensino de Educação Moral e Cívica no Primário e em nível superior para o magistério de ensino médio e superior, bem como supervisão em todos os três níveis de ensino. Ao CFE caberia fixar o currículo mínimo dos cursos de formação superior. Cf. AGUIAR, 1975. Os documentos disponíveis na íntegra neste livro.

${ }^{7}$ Cf. NATHANAEL, 1972, p.179. Faremos referência às páginas em que as citações foram retiradas no decorrer do texto.

${ }^{8}$ Sobre a obrigatoriedade de Estudos de Problemas Brasileiros e Organização Social e Política do Brasil Cf. nota 6.

${ }^{9}$ O Decreto Federal n 69.450, de $1^{\circ}$ nov. 1971, estabeleceu em seu Art. 20: "A educação física, desportiva e recreativa integrará, como atividade escolar regular, o currículo dos cursos de todos os graus de qualquer sistema de ensino”. Cf. AGUIAR, 1975.

${ }^{10}$ Este trecho faz parte de Denúncia divulgada no Boletim Informativo da Anpuh/Seção São Paulo, de set. 1980. Utilizamos a versão disponível em MARTINS, 2000, p.120.

${ }^{11}$ Para uma análise dos resultados deste Grupo, cf.: FENELON, 1983; MESQUITA; ZAMBONI, 2008; MESQUITA, 2008.

${ }^{12}$ Sobre as Diretrizes Curriculares Nacionais para os Cursos de História cf.: RICCI, 2003; FONSECA; COUTO, 2008, p.101-130.

${ }^{13}$ Sobre os saberes docentes cf.: BORGES, 2002; CIAMPI, 2008; TARDIF, 2002.

Artigo recebido em dezembro de 2012. Aprovado em agosto de 2013. 